\title{
ARBORESCENT PALM SEED MORPHOLOGY AND SEEDLING DISTRIBUTION
}

\author{
RODOLFO SALM \\ School of Environmental Sciences, University of East Anglia Norwich, Norfolk, NR4 7TJ, ENGLAND \\ Correspondence to: Rodolfo Salm, Programa de Pós-graduação em Ecologia e Recursos Naturais, \\ Universidade Federal de São Carlos, Rod. Washington Luís, km 235, Monjolinho, \\ CEP 13565-905, São Carlos, SP, Brazil, e-mail: rodolfosalm@terra.com.br
}

Received October 1, 2003 - Accepted February 17, 2004 - Distributed November 30, 2005

(With 1 figure)

\begin{abstract}
This study examines how the seed morphology of two large arborescent palms, Attalea maripa (Aubl.) Mart. and Astrocaryum aculeatum G. Mey, may affect their seed shadow in a seasonally dry Amazonian forest. In addition to being smaller and produced in larger numbers than those of A. aculeatum, A. maripa seeds also presented a substantially lower amount of nutritional reserves available for the embryo. However, A. maripa seedlings were found in much higher numbers than those of A. aculeatum. The results suggest that, within the spatial scale considered, the seed rain of A. maripa is more restricted to the area surrounding around reproductive conspecifics than that of A. aculeatum. Furthermore, in comparison with those of A. aculeatum, the smaller seeds of A. maripa might be less attractive to scatterhoarding rodents (e.g. Dasyprocta aguti). The pattern observed emphasizes the importance of scatterhoarding rodents as dispersers of large-seeded plant species in Neotropical forests.
\end{abstract}

Keywords: Amazonia, Astrocaryum aculeatum, Attalea maripa, scatterhoarding, seed shadow.

\section{RESUMO}

\section{Morfologia de sementes e distribuição de plântulas de palmeiras arborescentes}

Foi investigada a relação da morfologia das sementes de duas palmeiras arborescentes de grande porte, Attalea maripa (Aubl.) Mart. e Astrocaryum aculeatum G. Mey, com a chuva de sementes, em uma floresta amazônica sazonalmente seca. As sementes de A. maripa são menores e produzidas em maiores quantidades que aquelas de A. aculeatum. Tais sementes também têm uma quantidade de reservas nutricionais disponível para o embrião substancialmente menor. As plântulas de A. maripa foram encontradas em números muito maiores que as de A. aculeatum. Os resultados sugerem que, na escala espacial considerada, a chuva de sementes de A. maripa é mais restrita ao redor de palmeiras reprodutivas que aquela de A. aculeatum. As sementes de A. maripa, menores, devem ser menos atraentes para roedores que estocam seu alimento difusamente enterrando-o (e.g. Dasyprocta aguti). O padrão observado enfatiza a importância de tais roedores como dispersores de sementes de grande porte nas florestas neotropicais.

Palavras-chave: Amazônia, Astrocaryum aculeatum, Attalea maripa, estocagem dispersa, chuva de sementes. 


\section{INTRODUCTION}

Seed size and shape represent compromises between constraints associated with the most efficient means for both packing and dispersing embryo reserves (Harper et al., 1970). There is an obvious trade-off between seed size and number since small seeds can be produced in much larger quantities than larger ones for any given amount of overall reproductive investment. Thus, there is always a selective pressure for the production of larger quantities of smaller seeds (Harper et al., 1970; Fenner, 1985).

The benefits of large seed-size for plant survival are relatively higher in environments where seedlings experience density stress. Under such conditions, large seeds have a better chance of establishing themselves because of their larger nutritional reserves. Such reserves, stored within the seed, enable the seedling to produce a more extensive root system and to have a greater initial growth. Thus, single large seeds can produce large and more vigorous seedlings that have a higher establishment and recruitment probability (Harper et al., 1970; Fenner, 1985; Saverimuttu \& Westoby, 1996; Walters \& Reich, 2000).

Much of the enormous inter-specific variation in seed shape in plants is related to seed dispersal mechanisms (Fenner, 1985; Foster, 1986). The size and shape of seeds can also influence plant establishment probability by affecting the distance over which seeds can be dispersed.

With respect to plant distribution and abundance, small-seeded species exhibit a wide range of abundance and distribution, whereas larger-seeded species generally present lower abundance and narrower distribution (Guo et al., 2000). Smaller seeds are likely to be ingested whole by a wider range of animal dispersal agents (Harper et al., 1970; Harper, 1977; Jackson, 1981; Howe \& Smallwood, 1982; Howe et al., 1985; Fenner, 1985; Foster, 1986; Hegde et al., 1991).

However, for large-seeded species, vertebrate predation is generally believed to be a disadvantage, presumably because their seeds represent a richer energy source and are more visible than small seeds are to vertebrates. Thus, the advantages of greater energy reserves associated with large seeds could be offset by possible dispersal limitations and predation risks (Vander Wall, 1990; Hulme, 1993).
For example, in Neotropical forests, caviomorph rodents such as agoutis (Dasyprocta spp.) and accouchis (Myoprocta spp.) have been described as important seed dispersers of neotropical large-seeded palms (Smythe, 1978; Forget, 1991, 1994). However, because these rodents habitually scatterhoard their prey-seeds, they may fail to retrieve a small proportion of them. Thus, they also function as seed dispersers (Smythe, 1978; Forget, 1990, 1994; Forget \& Milleron, 1992; Forget et al., 2001; Peres et al., 1997).

The Amazonian large arborescent palm Attalea maripa (Aubl.) Mart. has thick (> $30 \mathrm{~cm}$ DBH), tall, single stems with no spines. The fruits consist of a fibrous outer shell and mesocarp that somewhat viscous when immature. The seed is enclosed in a smooth woody yellowish-brown shell with a sharp point (Henderson et al., 1995). Almeida \& Dantas da Silva (1997) describe A. maripa seeds as being 3-4 $\mathrm{cm}$ in length and $2 \mathrm{~cm}$ in diameter. Although typically having 2 , the seeds may have from 1 to 3 kernels. These authors report an average $33 \%$ moisture content in the fresh fruit. The dry fruit mass averages $18 \mathrm{~g}$ and comprises the outer shell (16\%), mesocarp (26\%), woody inner shell (49\%), and oily kernels (9\%) (Almeida \& Dantas da Silva, 1997).

The upper parts of the massive trunks of Astrocaryum aculeatum G. Mey, also a large arborescent palm restricted to the Amazon (Henderson et al., 1995), have long black spines arranged in regularly spaced rings. As the palm grows, the old spines fall, and the lower parts of the trunk typically become bare. The yellowish-green fruit of A. aculeatum palms consists of a dense, yellowish, farinaceous mesocarp that envelops a nearly black, woody shell. The single kernel is white, oily and hard, and covered with an adherent brown testa (Pesce, 1985; Almeida \& Dantas da Silva, 1997).

The aim of this study is to examine the effects of seed size and shape on seedling distribution; this will be done through a comparative study of A. maripa and A. aculeatum in a seasonally dry Amazonian forest. Laboratory measurements of seed anatomy will be considered together with mapping of seedlings and adults of both species growing in a 16 ha grid system that crosses two areas presenting contrasting forest structure and floristic composition. 


\section{METHODS}

Seeds of Attalea maripa (Aubl.) Mart. and Astrocaryum aculeatum G. Mey were collected at the Pinkaití Research Station $\left(7^{\circ} 46^{\prime} 18^{\prime \prime} \mathrm{S}\right.$; $\left.51^{\circ} 57^{\prime} 42^{\prime \prime} \mathrm{W}\right)$, located along Riozinho River, a second-order tributary of the Xingu River. These were taken to the Plant Anatomy Laboratory of the University of São Paulo (USP) for measurement. Seed length and width were measured to the nearest millimeter. Seed volume was estimated following seed immersion in a graduated beaker. The seeds were broken and the kernel volume was measured. One fruiting palm tree of each species was destructively sampled; fruits were counted and used for seed predation and seed dispersal experiments.

Seed shadow is not always spatially congruent with seedling distribution (Rey \& Alcantara, 2000). However, because of the practical difficulty of determining seed shadow through direct means, I used the seedling distribution in relation to reproductive palms as a proxy measure. Furthermore, since seedlings of A. maripa and A. aculeatum differ morphologically, arbitrary boundaries were set for their respective definitions. Thus, A. maripa seedlings were defined as plants having petioles of up to $7 \mathrm{~mm}$ in diameter measured at $10 \mathrm{~cm}$ from the ground. For A. aculeatum, the limit was $4 \mathrm{~mm}$ at the same height.

The seedling distribution pattern of A. maripa and $A$. aculeatum in relation to reproductive adults of each species was quantified within a 16 ha section of the main grid system at Pinkaití. This grid system progresses from an open forest with a high abundance of arborescent palms in its western portion, to a more built-up forest where palm trees were rare in the eastern portion. To investigate palm seedling distribution of each species in relation to reproductive adults, the grid area was demarcated with flag stakes placed at $25 \mathrm{~m}$ intervals, creating 0.0625 ha subplots. Within this area, all adult trees of each palm species were mapped and tagged. Thereafter, every adult A. maripa and A. aculeatum palm was inspected for evidence of past reproductive activity, i.e., accumulation of old seed remnants beneath the crown. Here, the term "reproductive" denotes fruit-producing individuals, which excludes palms that may also be reproductive through pollen production from male flowers.

Since marked differences were found in the abundance of A. maripa and A. aculeatum seedlings, their respective spatial distributions were estimated with two different methodologies. Thus, A. maripa seedlings, found to be more abundant than those of A. aculeatum, were sampled within $1005 \times 5 \mathrm{~m}$ plots, which were regularly spaced across the grid system. The much rarer seedlings of A. aculeatum were exhaustively sampled throughout the entire grid system. Two previously trained field assistants searched each 0.0625 ha plot, where all seedlings were located. Using tape and a compass, they tagged and mapped each in relation to the nearest grid stake.

\section{RESULTS}

The elongated seeds of Attalea were significantly smaller than the globose seeds of Astrocaryum (t- test, $\mathrm{p}<0.001$; Fig. 1, Table 1). The seeds of Attalea had 1, 2, or 3 loci $(38.7 \%$, 38.7, and $22.5 \% \mathrm{~N}=31$ ) whereas Astrocaryum seeds always had one locus with a single embryo. A total of 2283 fruits were counted from a single bunch of a felled Attalea tree. In contrast, the Astrocaryum tree had three bunches and a total of 557 fruits (mean of 186 fruits per bunch).

The density of reproductive Attalea palms in the forest plots with high palm density (26.2 trees.ha $^{-1}$ ) was significantly higher than that of the low palm-density forest eastwards (2.5 trees.ha ${ }^{-1}$ ) (Mann-Whitney $\left.\mathrm{U}, \mathrm{p}=0.001\right)$. In the grid system as a whole, there was a significant negative correlation between the seedling density

TABLE 1

Volume of A. maripa and A. aculeatum seeds collected at the Pinkaití Research Station, Brazil.

\begin{tabular}{|l|l|c|}
\hline \multirow{2}{*}{} & \multicolumn{2}{|c|}{ Mean \pm S. D. (min.-max.) } \\
\cline { 2 - 3 } & \multicolumn{2}{|c|}{ Mstrocaryum maculeatum $\mathbf{n}=\mathbf{1 2}$} \\
\hline Seed volume $(\mathrm{mL})$ & $9.2 \pm 2.5(5-17)$ & $32.5 \pm 8.5(16-44)$ \\
\hline Endosperm volume $(\mathrm{mL})$ & $1.9 \pm 0.6(1.0-3.0)$ & $12.0 \pm 3.6(7.0-15.0)$ \\
\hline
\end{tabular}




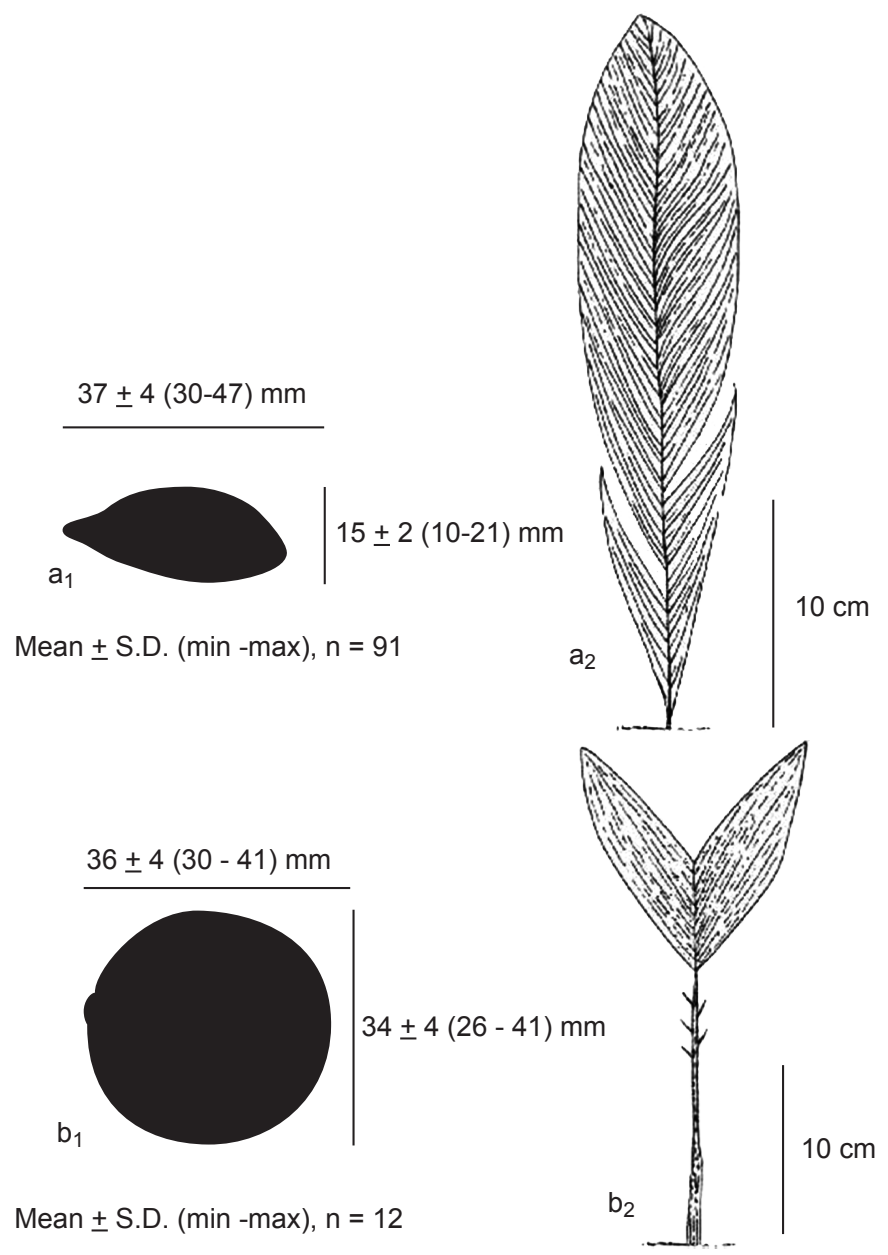

Fig 1. - Dimensions of a) Attalea maripa and b) Astrocaryum aculeatum 1) seed and 2) seedling.

of this species and distance to reproductive Attalea trees $\left(\mathrm{r}_{\mathrm{s}}=-0.366, \mathrm{p}<0.001\right)$. Seedling abundance was positively correlated with reproductive palm density $\left(10 \mathrm{~m}: \mathrm{r}_{\mathrm{s}}=0.221, \mathrm{p}=0.014 ; 20 \mathrm{~m}: \mathrm{r}_{\mathrm{s}}=0.290\right.$, $\left.\mathrm{p}=0.002 ; 50 \mathrm{~m}: \mathrm{r}_{\mathrm{s}}=0.284, \mathrm{p}=0.002\right)$. However, there was a significantly higher density of Attalea seedlings in this high palm-density area (t-test, $\mathrm{p}<0.001)$. These relationships were not significant when only the high palm-density $\left(10 \mathrm{~m}: \mathrm{r}_{\mathrm{s}}=0.078\right.$, $\mathrm{p}=0.275 ; 20 \mathrm{~m}: \mathrm{r}_{\mathrm{s}}=0.090, \mathrm{p}=0.244 ; 50 \mathrm{~m}$ : $\left.r_{s}=0.207, p=0.055\right)$ or the low palm-density (10 m: $\mathrm{r}_{\mathrm{s}}=-0.180, \mathrm{p}=0.256 ; 20 \mathrm{~m}: \mathrm{r}_{\mathrm{s}}=0.179$, $\left.\mathrm{p}=0.144 ; 50 \mathrm{~m}: \mathrm{r}_{\mathrm{s}}=0.253, \mathrm{p}=0.061\right)$ areas were considered.

The density of reproductive Astrocaryum trees in the high-density portion of the grid was significantly higher than that of low palm-density (Mann-Whitney U, p = 0.013). The seedlings of this species, in turn, were significantly less abundant in the low palm-density half of the grid (Mann-Whitney U, $\mathrm{p}<0.001)$. There was no spatial correlation between the abundance of seedlings and the abundance of reproductive adults of this species (high and low-density: $\mathrm{r}_{\mathrm{s}}=-0.086, \mathrm{p}=0.228$; high-density: $r_{s}=-0.009, p=0.459 ;$ low-density: $r_{s}=0.017$, $\mathrm{p}=0.444)$

\section{DISCUSSION}

Although there was no difference in seed length between the two species $(\mathrm{p}=0.680)$, the seeds of Attalea were significantly narrower than 
those of Astrocaryum ( $<<0.001)$, whose length and width were roughly equivalent. Also, A. maripa seeds presented up to three embryos each, while those of A. aculeatum invariably had only one.

Thus, Attalea seeds had significantly smaller endosperm reserves available for seedling development than those of Astrocaryum ( $p<0.001$ ), which was compensated for by the far greater fruit crop size of the former. This represents a trade-off in that, while the long-shaped seeds of A. maripa carry smaller nutrient reserves, they may be ingested by some vertebrate species, whereas seed dispersal of A. aculeatum is only carried out by scatterhoarding rodents.

Large quantities of A. maripa seeds were found in tapir (Tapirus terrestris) dung piles at Pinkaití, which is consistent with observations made elsewhere in the Amazon (Bodmer, 1990; Fragoso, 1997). Seeds of A. maripa have also been found in tortoise (Geochelone sp.) feces at this site (Jerozolimski, 2005). The Kayapó Indians have also reported finding A. aculeatum seeds in tapir feces. However, given the size of these seeds, this probably occurs rarely as no A. aculeatum seeds were found in a number of dung piles inspected, and no other species is likely to ingest these seeds whole.

The seedlings of A. maripa are widespread in terra- firme forest areas at Pinkaití, with results showing that these seedlings were up to two orders of magnitude more abundant than those of $A$. aculeatum. The larger number of fruit-producing trees of this species, the greater seed-crop size, and the broader spectrum of animal dispersal agents may all explain this difference. This comparative study also showed that seedlings of the smallerseeded A. maripa are more densely clumped around reproductive trees than those of the larger-seeded $A$. aculeatum, suggesting that the seed shadow of $A$. maripa is more restricted than that of A. aculeatum. Needless to say, this pattern is unlike that found for wind or gut-dispersed species (Harper et al., 1970; Harper, 1977; Howe and Smallwood. 1982; Fenner, 1985).

The wider seed shadow of A. aculeatum might be a consequence of this species's stronger mutualistic relationship with caviomorph rodents. Thus, because larger seeds contain greater food reserves, scatterhoarding rodents preferentially remove large seeds and tend to disperse them farther (Vander Wall, 1990). In addition, the fruits of $A$. aculeatum are an important food source for agoutis at Pinkaití, particularly during the dry season when alternative food resources for this species are scarce (Jorge, 2000).

This study supports the view that caviomorph rodents are especially important in large-seeded plant dispersal because of their high relative abundance and widespread distribution. Furthermore, by decreasing the probability of seed predation and by actively promoting seedling establishment, burying seeds in scattered caches potentially enhances plant recruitment.

Acknowledgements - I wish to thank Dr. Euphly Jalles-Filho for his advice at every stage of this study, which was funded by the Coordenação de Aperfeiçoamento de Pessoal de Nivel Superior (CAPES), Conservation International, and the Wildlife Conservation Society. I also thank P. M. Arruda, N. V. Salles, and K. Kayapó for assistance during fieldwork; the Kayapó Community of A'Ukre for allowing me to work in their territory; and M. L. S. P. Jorge and A. Jerozolimski for critical support and useful comments on the manuscript.

\section{REFERENCES}

ALMEIDA, S. \& DANTAS DA SILVA P. J., 1997, As palmeiras: aspectos botânicos, ecológicos e econômicos, pp. 235-251. In: P. L. B. Lisboa (ed.), Caxiuanã, 446 p., Museu Goeldi, Belém.

BODMER, R. E., 1990, Fruit patch size and frugivory in the lowland tapir (Tapirus terrestris). J. Zool., Lon., 222: 121-128.

FENNER, M., 1985, Seed Ecology. Chapman and Hall, London, $151 \mathrm{p}$.

FORGET, P. M., 1990, Seed dispersal of Vouacapoua americana (Cesalpinaceae) by caviomorph rodents in French Guiana. J. Trop. Ecol., 6: 459-468.

FORGET, P. M., 1991, Scatterhoarding of Astrocaryum paramaca by Proechimys in French Guiana: comparisons with Myoprocta exilis. Trop. Ecol., 32: 155-167.

FORGET, P. M., 1994, Recruitment Pattern of Vouacapoua americana (Caesalpiniaceae), a Rodent-Dispersed Tree Species in French-Guiana. Biotropica, 26: 408-419.

FORGET, P. M. \& MILLERON T., 1992, Evidence for Secondary Seed Dispersal by Rodents in Panama. Oecologia, 87: 596-599.

FORGET, P. M., RANKIN-DE MERONA J. M. \& JULLIOT C., 2001, The effects of forest type, harvesting and stand refinement on early seedling recruitment in a tropical rain forest. J. Trop. Ecol., 17: 593-609.

FOSTER, S. A., 1986, On the adaptive value of large seeds for tropical moist forest trees: a review and synthesis. Bot. Rev., 52: 261-299.

FRAGOSO, J. M. V., 1997, Tapir-generated seed shadows: scale-dependent patchiness in the Amazon rain forest. $J$. Ecol., 85: 519-529. 
GUO, Q., BROWN J. H., VALONE T. J \& KACHMAN, S. D., 2000, Constraints of seed size on plant distribution and abundance. Ecology, 81: 2149-2155.

HARPER, J. L., LOVELL P. H. \& MOORE H.E., 1970, The shapes and size of seeds. Annu. Rev. Ecol. Syst., 1: 327-356.

HARPER, J. L., 1977, Population biology of plants. Academic Press, New York. 892 p.

HEGDE, S. G., SHAANKER R. U. \& GANESHAIAH K. N., 1991, Evolution of seed size in the bird-dispersed tree Santalum album L.: A trade off between seedling establishment and dispersal efficiency. Evol. Trend Plants, 5: 131-135.

HENDERSON, A., GALEANO G. \& BERNAL R., 1995, Field guide to the palms of the Americas. Princeton University Press, Princeton. 363 p.

HOWE, H. F. \& SMALLWOOD J., 1982, Ecology of seed dispersal. Annu. Rev. Ecol. Syst., 13: 201-228.

HOWE, H. F., SCHUPP E. W. \& WESTLEY L. C., 1985, Early consequences of seed dispersal for a Neotropical tree (Virola surinamensis). Ecology, 66: 781-791.

HULME, P. E., 1993, Post-dispersal seed predation by small mammals. Symp. Zool. Soc. Lond., 65: 268-287.

JACKSON, J. F., 1981, Seed size as a correlate of temporal and spatial patterns of seed fall in a neotropical forest. Biotropica, 13: 121-130.

JEROZOLIMSKI, A., 2005, Padrões de atividade e utilização de recursos por jabutis (Geochelone denticulata e G. carbonaria - Cryptodira: Testudinidae) e o impacto da caça dos índios Kayapós sobre suas populações. Tese de Doutorado, Departamento de Ecologia, 242 p., Universidade de São Paulo, São Paulo.
JORGE, M. L., 2000, Área de vida, atividade diárea e densidade populacional de cotias na estação de pesquisas PinkaitíAmazonia Oriental (Se-Pará). MsC thesis, University of São Paulo, São Paulo.

PERES, C. A., SCHIESARI, L. C. \& DIAS LEME, C. L., 1997, Vertebrate predation of Brazil-nuts (Bertholletia excelsa, Lecythidaceae), an agouti-dispersed Amazonian seed crop: A test of the escape hypothesis. J. Trop. Ecol., 13: 69-79.

PESCE, C., 1985, Oil palms and other oil seeds of the Amazon. Algonac, Michigan. 200 p.

REY, P. J. \& ALCANTARA J. M., 2000, Recruitment dynamics of a fleshy-fruited plant (Olea europaea): connectivity patterns of seed dispersal to seedling establishment. $J$. Ecol., 88: 622-633.

SAVERIMUTTU, T., \& WESTOBY, M., 1996, Seedling longevity under deep shade in relation to seed size. J. Ecol., 84: 681-688.

SMYTHE, N., 1978, The natural history of the Central American agouti (Dasyprocta punctuata). Smithson. Contrib. Zool., 257: 1-152.

STEBBINS, G. L., 1971, Adaptive radiation of reproductive characteristics in angiosperms. II. Seeds and seedlings. Ann. Rev. Ecol. Syst., 2: 237-260.

TOMLINSON, P. B., 1990, The structural biology of palms. Clarendon Press, Oxford. 492 p.

VANDER WALL, S. B., 1990, Food hoarding in animals. University of Chicago Press, Chicago. 446 p.

WALTERS, M. \& REICH P. B., 2000, Seed size, nitrogen supply and growth rate affect tree seedling survival in deep shade. Ecology, 81: 1887-1901. 